\title{
PENERAPAN STRATEGI RECIPROCAL TEACHING DAN PERTANYAAN KRITIS (HIGHER ORDER THINKING) UNTUK MENINGKATKAN PRESTASI MEMBACA PEMAHAMAN PADA TEKS DISKUSI
}

\author{
Sri Hariyati \\ SMA Laboratorium UM, Kota Malang, Jawa Timur \\ Email: sri_hariyati70@yahoo.com
}

\begin{abstract}
Abstrak
Penelitian ini bertujuan untuk meningkatkan prestasi membaca pemahaman teks diskusi dengan menerapkan Reciprocal Teaching dan pertanyaan kritis (Higher Order Thinking (HOT) di kelas XII SMA Laboratorium UM. Desain penelitian yang digunakan adalah penelitian tindakan kelas dengan dua siklus. Hasil yang diperoleh pada siklus pertama, rata-rata nilai post-test I adalah 61.29\% dimana hanya 13 mampu mencapai Kriteria Ketuntasan Minimal (KKM), kemudian pada siklus kedua meningkat menjadi 76.21\%, dengan 21 peserta didik yang mampu mencapai KKM. Selanjutnya, keaktifan peserta didik dalam diskusi kelas juga mengalami perbaikan, dimana pada siklus pertama persentase keaktifan peserta didik hanya $30 \%$ dan kemudian meningkat menjadi 70\% pada siklus kedua. Dari hasil ini, maka strategi reciprocal teaching dapat dijadikan alternatif untuk meningkatkan kemampuan membaca jenis teks diskusi.
\end{abstract}

Kata kunci: reciprocal teaching, pertanyaan HOT, membaca pemahaman, teks diskusi

\section{Latar Belakang}

Peningkatan kemampuan membaca pemahaman adalah penting untuk mendukung kemampuan membaca yang mampu meningkatkan kemampuan akademik dan profesi. Oleh karena itu, kemampuan membaca yang mampu mengaktifkan berpikir tingkat tinggi (Higher Order Thinking (HOT) menjadi sebuah tantangan yang menarik saat ini.

Permasalahan yang muncul kemudian adalah bagaimana meningkatkan kemampuan membaca pemahaman yang mengaktifkan penalaran peserta didik. Berdasarkan wawancara langsung dengan beberapa peserta didik dan guru, disebutkan bahwa selama ini mata pelajaran bahasa Inggris untuk keterampilan membaca jenis teks diskusi merupakan materi membaca pemahamannya yang sulit. Hal ini dikuatkan dari hasil tes pra-siklus yang menunjukkan hasil bahwa hanya 10 dari 32 peserta didik yang mampu meraih nilai tuntas dengan KKM 70.

Permasalahan berikutnya adalah dari model pembelajaran yang selama ini peneliti lakukan di kelas. Model pembelajaran yang diimplementasikan masih belum sesuai dengan tingkat kesulitan jenis teks diskusi karena teks diskusi membutuhkan pola berpikir penalaran. Sementara itu, teks diskusi ini merupakan teks yang menampilkan makna berupa pendapat penulis dengan dua sisi pendapat yang pro dan kontra. Sehingga, untuk menganalisis dua pendapat yang berlawanan membutuhkan pemikiran kritis (Higher Order Thinking Skill). Dari permasalahan tersebut peneliti mengupayakan penyelesaian dengan melakukan penelitian tindakan kelas.

Dalam penelitian terdahulu yang dilakukan oleh Sholihah dan Widyantoro (2014) dinyatakan bahwa kemampuan berpikir kritis, kemampuan kosa kata dan motivasi dapat mempengaruhi prestasi membaca pemahaman. Hasil penelitian tersebut memotivasi peneliti untuk melakukan tindak lanjut dari hasil penelitian yang mereka peroleh dengan menghadirkan sebuah model pembelajaran yang bernama reciprocal teaching dan pertanyaan kritis (HOT) yang bertujuan untuk memperbaiki prestasi membaca peserta didik pada jenis bacaan teks diskusi. 
Rangkuman dari langkah-langkah strategi pembelajaran reciprocal teaching dan pertanyaan HOT merujuk pada penelitian yang dilakukan Palinscar dalam Suyitno (2006:34), pertama, guru menyajikan model bagaimana mengajarkan teks diskusi di depan kelas. Kedua, kelompok diberi media pembelajaran berupa potongan paragraf teks diskusi yang diacak. Mereka diminta menata paragraf acak tersebut secara berurutan sesuai struktur teks diskusi yang benar. Ketiga, kelompok diminta melengkapi graphic organizer yang membahas tentang unsur kebahasaan teks. Keempat, Guru membuat kompetisi antar kelompok untuk menemukan susunan paragraf dan unsur kebahasaan, kelompok yang mampu menjawab dengan benar mendapat reward. Kelima, guru meminta 2 anggota dari tiap kelompok "bertamu" ke kelompok lain, tugas yang bertamu menjelaskan hasil analisis teks diskusi dari kelompoknya, karena tiap kelompok tema teks diskusinya tidak sama. Kelompok yang didatangi menyimak penjelasan kelompok tamu. Keenam, setelah kembali ke kelompok asal, guru meminta tiap kelompok memberikan pendapat pro atau kontra serta alasan terhadap teks diskusi mereka, mereka menuliskan pendapat mereka di lembar kerja yang sudah disediakan. Ketujuh, guru meminta lembar pendapat kelompok untuk ditukar ke kelompok yang tadi didatangi, selanjutnya kelompok yang mendapat lembar kelompok lain tersebut memberikan feedback. Kedelapan, guru menutup pembelajaran dengan berbagi (sharing) pendapat antar kelompok dan memberi penguatan.

Model pembelajaran Reciprocal Teaching ini menginspirasi peneliti karena ada tiga hal penting dari model pembelajaran tersebut untuk diterapkan penelitian ini yaitu (1) model ini diharapkan mampu merangsang peserta didik untuk membangun pemahaman sendiri dengan berpikir kritis, (2) memotivasi peserta didik untuk menyampaikan informasi dengan analisis yang benar, (3) menguatkan pemaknaan $4 \mathrm{C}$ (Collaborative, Communicative, Critical dan Creation) seperti yang tertulis dalam kurikulum 2013 yang direvisi.

\section{METODE PENELITIAN}

Desain penelitian tindakan kelas dipilih untuk mengolah penelitian ini karena desain ini sesuai memperbaiki kualitas belajar dan mengajar di kelas. Peneliti merujuk pada model penelitian tindakan kelas yang dirancang oleh Kemmis \& Mc. Taggart (1988, halaman 14) di dalam Latief (2014, halaman 144) yang terdiri dari 4 langkah: (1) perencanaan, (2) pelaksanaan, (3) pengamatan, dan (4) refleksi.

Penelitian ini dilaksanakan di kelas XII IPS Lintas Minat SMA Laboratorium UM yang memiliki 32 peserta didik. Data diambil dengan menggunakan tiga instrumen penelitian yaitu tes membaca (tes pra-siklus dan post test) dengan jenis teks diskusi, angket motivasi peserta didik, dan angket pengamatan keaktifan kerja kelompok. Jenis teks yang digunakan adalah jenis teks diskusi yang digunakan sebagai materi yang dipakai dalam implementasi strategi Reciprocal Teaching dan pertanyaan kritis (Higher Order Thinking).

\section{HASIL PENELITIAN}

Analisis hasil penelitian pada tahap pra-siklus, siklus I dan siklus 2 ini meliputi tiga hal yaitu, hasil nilai pra-siklus, post test I, post test II, observasi keaktifan peserta didik dalam diskusi kelas dan kuisioner motivasi peserta didik terhadap strategi pembelajaran yang diimplementasikan. Dari Diagram 1, bisa dilihat kondisi perubahan pada tiap tahapan siklus. 


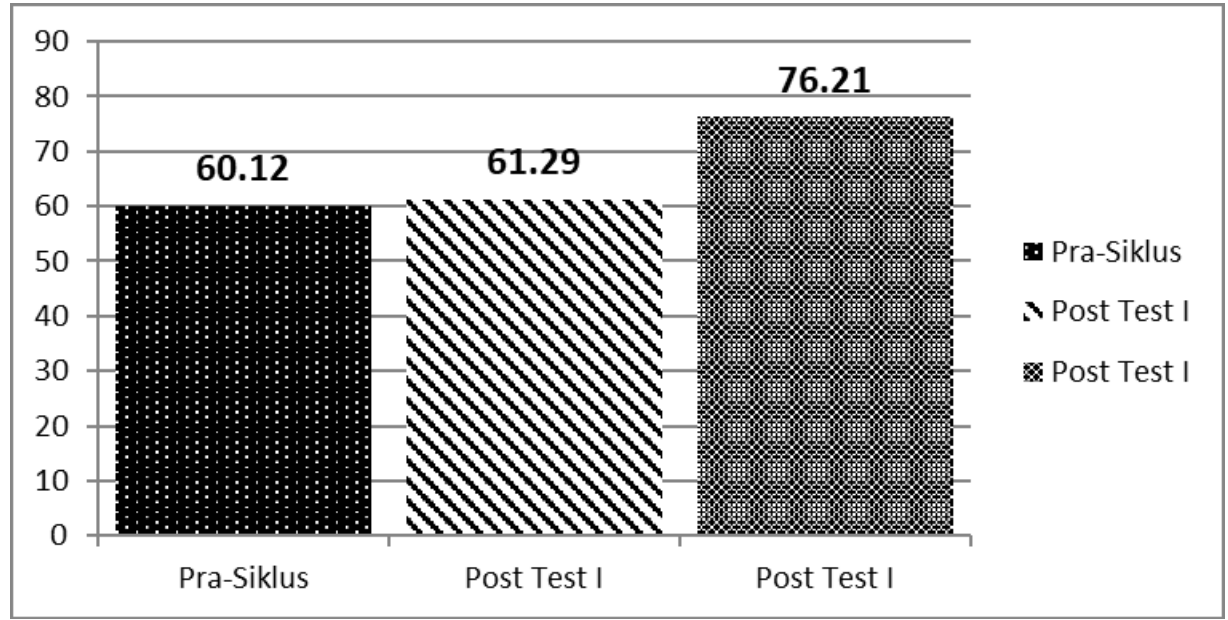

Keterangan:

KKM: 70

Rata-rata nilai: Pra-Siklus: 60.12, Siklus 1: 61.29, Siklus 2: 76.21

Jumlah peserta didik yang Tidak Tuntas: Pra-Siklus: 22, Siklus 1: 19, Siklus 2: 11

Jumlah peserta didik yang Tuntas: Pra-Siklus: 10, Siklus 1: 13, Siklus 2: 21

\section{Hasil Penelitian Siklus I}

Hasil yang diperoleh pada siklus pertama dianalisis berdasarkan data yang diperoleh dari tiga instrumen yaitu tes pra-siklus, Post Test I dan angket pengamatan keaktifan kerja kelompok. Pada saat siklus pertama, Kompetensi Dasar (KD) yang sedang diajarkan adalah KD ke-3.6 yakni tentang analisis Teks Diskusi. Selanjutnya, hasil Post Test I diperoleh nilai rata-rata 61.29, angka tersebut masih dibawah nilai KKM. Jika dibandingkan dengan rata-rata nilai pada tes pra-siklus, maka peningkatan nilai yang bisa mencapai KKM hanya dialami oleh 3 peserta didik saja, kondisi ini bisa diperjelas dengan mengamati Diagram 1.

Sementara itu, hasil pengamatan keaktifan peserta didik yang diwujudkan dalam kegiatan implementasi strategi pembelajaran reciprocal teaching dan pertanyaan HOT, menunjukkan ratarata keaktifan peserta didik yang hanya memiliki rata-rata $30 \%$ saja. Kondisi ini masih sangat kurang memuaskan dan belum bisa memenuhi harapan yang ingin dicapai dalam penelitian.

Berdasarkan Rancangan Pelaksanaan Pembelajaran (RPP), langkah pertama dari proses pembelajaran adalah guru memberikan apersepsi tentang teks discussion dengan menayangkan contoh teks discussion di layar LCD. Kemudian peserta didik membentuk kelompok. Kegiatan kelompok selanjutnya adalah mengerjakan media pembelajaran berupa jumbled paragraphs atau paragraf yang di acak, kelompok diminta untuk menata potongan paragraf dari teks discussion yang susunannya masih acak, kegiatan menyusun paragraf ini membutuhkan analisis yang merupakan kegiatan berpikir kritis, dimana kelompok harus menganalisis urutan paragraf sesuai generic structure untuk teks discussion. Selanjutnya, setelah selesai menyusun paragraf, kelompok diminta melengkapi graphic organizer yang isinya tentang analisis dari sisi kebahasaan.

Bagi kelompok yang berhasil menyusun dengan benar mendapat reward stiker, jumlah stiker yang diperoleh kelompok menjadi gambaran tentang keaktifan dan ketepatan hasil kerja dan analisis kelompok, kemudian kelompok bekerja untuk memberi pendapat dan saling merespons pendapat kelompok lain. Hasil pengamatan keaktifan kerja kelompok bisa dilihat pada Tabel 1 berikut ini. 
Tabel 1. Hasil Pengamatan Keaktifan Kelompok pada Siklus I

\begin{tabular}{clll}
\hline Kelompok & Nama anggota kelompok & $\begin{array}{c}\text { Jumlah } \\
\text { Stiker }\end{array}$ & \multicolumn{1}{c}{ Judul Text } \\
\hline 1 & AM, ASD, EDF, NNF & 5 & School Uniforms Policy \\
\hline 2 & WD, ACR, MAW, SAY & 4 & $\begin{array}{l}\text { Should the Death Penalty Be } \\
\text { Allowed }\end{array}$ \\
\hline 3 & LLK, RRA, AYI, MNF & 4 & School Uniforms Policy \\
\hline 4 & ARN, DSP, DKR, RSD & 5 & Tablet vs Books \\
\hline 5 & AMM, MWA, PBT, ZA & 2 & $\begin{array}{l}\text { Should the Death Penalty Be } \\
\text { Allowed }\end{array}$ \\
\hline 6 & AA, RPN, RPN, SS & 4 & Nuclear Energy \\
\hline 7 & WPP, FHK, AIM, RAW & 3 & Tablet vs Books \\
\hline 8 & AAL, AZ, MIA, LW & 4 & Nuclear Energy \\
\hline
\end{tabular}

Dari Tabel 1 tersebut, ada dua kelompok yaitu kelompok 5 dan 7 yang keaktifan dalam berdiskusi dan menganalisa teks masih dianggap kurang dibandingkan dengan kelompok lain. Pada dasarnya tahapan kegiatan pembelajaran sesuai RPP yang telah dibuat, telah meminta kelompok untuk tidak hanya mengerjakan masalah yang dipaparkan mengenai teks discussion, tapi juga diminta untuk browsing di internet dalam mencari issue terkait dengan topik bacaan dari teks diskusi. Pada siklus I ini, peserta didik di kelompok tersebut belum terlalu tanggap untuk melakukan kegiatan mencari ide kritis walaupun guru memberi ijin memanfaatkan fasilitas jaringan internet yang ada di sekolah. Namun demikian, fakta yang terjadi saat pembelajaran adalah beberapa peserta didik masih menulis ulang kata-kata yang ada dalam teks bacaan tanpa berusaha mengkritisi dan menambah pemikiran baru. Kelompok tersebut masih memiliki kecenderungan menerima informasi teks apa adanya.

Sementara itu pada kelompok 1 dan kelompok 4, yaitu kelompok yang perolehan stikernya paling banyak, mereka aktif berpendapat dan mendiskusikan topik yang dijadikan permasalahan dalam diskusi kelompok, bahkan mereka aktif berpendapat dengan menambahkan ide sendiri dari berbagai artikel yang relevan dengan topik bacaan yang mereka olah dengan analisis kelompok dari berbagai informasi melalui jaringan internet di kelas.

Pada siklus I ini guru menerapkan strategi reciprocal teaching yang bermakna menyampaikan informasi dari teks discussion ke kelompok lain, hal ini dilakukan setelah terlebih dahulu kelompok melakukan analisis sendiri, terutama tentang pendapat pro dan kontra yang disajikan penulis. Kemudian kelompok juga menganalisis aspek kebahasaan yang diterapkan dalam teks tersebut dan membuat pendapat kelompok.

Berikut ini adalah kutipan dari pendapat kelompok 1 dan respon balikan dari kelompok 3. Topik bacaan yang disajikan adalah tentang "School Uniforms Policy": I am agree if school uniform are important because it will not make differentiate whether the student are rich or not and student economic or social class. Arti dari pendapat tersebut adalah bahwa mereka setuju kebijakan tentang adanya seragam karena hal ini tidak akan menyebabkan terciptanya pembeda dari sisi ekonomi dan kelas. Sementara itu respon balikan dari kelompok 4 terhadap pendapat kelompok 1 tersebut adalah: This opinion, it's true, by making same uniform we cannot discriminate.

Pendapat-pendapat kelompok tersebut menggunakan bahasa Inggris yang mungkin secara grammatical terdapat kesalahan tetapi maknanya bisa dipahami dengan cukup baik. Pendapat tersebut di atas adalah respon dari pertanyaan kritis dari guru "Which side do you agree? Why? Write your reasons briefly", yang artinya "Pada sisi pendapat yang manakah anda menyetujui? Mengapa? Tulislah alasan-alasan anda dengan ringkas dan jelas." Pertanyaan kritis ini untuk melatih berpikir kritis pada peserta didik, dan contoh kutipan jawaban kelompok yang sudah 
disebutkan di atas sudah menampakkan adanya pemikiran kritis yang muncul dari peserta didik pada siklus 1, walaupun belum banyak jumlahnya.

\section{Refleksi Strategi Pembelajaran Siklus I}

Refleksi pada siklus 1 bertujuan untuk memperbaiki kekurangan yang terjadi pada implementasi pembelajaran di siklus 1, perbaikan ini berfokus pada upaya meningkatkan kemampuan peserta didik dalam berpikir kritis (Higher Order Thinking) pada pelajaran membaca pemahaman teks diskusi. Pada siklus 1, keaktifan peserta didik dalam diskusi kelompok untuk membahas lembar kerja peserta didik masih kurang maksimal dan ini berdampak pada hasil post test I yang kurang memuaskan.

Dari kekurangan tersebut, perbaikan yang dilakukan peneliti adalah memperbaiki susunan anggota kelompok diskusi, pada siklus kedua ini anggota kelompok merupakan kombinasi dari peserta didik yang berkemampuan rendah, menengah dan tinggi. Revisi ini bertujuan agar dalam kerja kelompok dan diskusi kelas antar anggota kelompok bisa saling berbagi ide dalam menyelesaikan tugas secara optimal, dengan harapan peserta didik yang memiliki kemampuan rendah bisa termotivasi untuk mampu memahami teks bacaan yang akhirnya mereka dapat meraih prestasi membaca yang lebih baik.

\section{Hasil Penelitian Siklus II}

Hasil yang diperoleh pada siklus kedua ini merupakan hasil implementasi strategi pembelajaran setelah dilakukan perbaikan yang bisa dilihat dari hasil post test kedua dan rekapitulasi jumlah stiker untuk keaktifan peserta didik dalam proses belajar. Diagram 1 menggambarkan adanya perubahan pada nilai rata-rata dari siklus pertama ke siklus kedua yang menunjukkan peningkatan yang cukup baik. Ada dua kali pertemuan pada siklus kedua ini, yaitu saat implementasi strategi pembelajaran dan post test.

Peneliti juga memfokuskan perhatian pada kemampuan berpikir kritis peserta didik dalam menganalisis teks diskusi. Pada Diagram 1 dapat dilihat bahwa di Siklus II, peserta didik mampu menunjukkan peningkatan prestasi membaca pemahaman pada teks diskusi dan yang mencapai kriteria sukses sebanyak 21 peserta didik dengan rata-rata nilai yang meningkat dari 61,29 pada siklus pertama menjadi 76,21 pada siklus kedua. Sementara itu keaktifan peserta didik dalam diskusi kelas juga mengalami peningkatan, pada Siklus I, persentase keaktifan hanya 30\%, kemudian pada Siklus II meningkat menjadi $70 \%$.

Dari perkembangan ini, maka penelitian dilakukan hanya sampai Siklus II karena hasil yang diperoleh sudah menunjukkan keberhasilan. Diagram 2, memberi gambaran perubahan hasil pengamatan keaktifan peserta didik pada diskusi kelas.

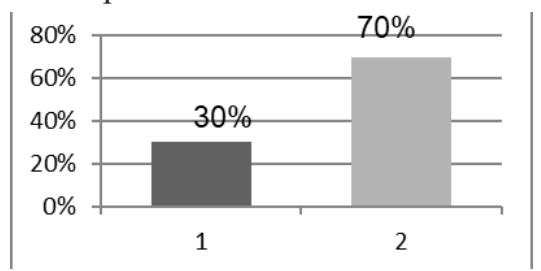

Siklus I Siklus II

Diagram 2: Perbandingan Hasil Pengamatan Keaktifan Peserta Didik 


\section{PEMBAHASAN}

Ada beberapa hal penting yang bisa dikupas dari hasil penelitian ini. Pertama, strategi ini membangun kebiasaan berpikir kritis peserta didik bila pemberian pertanyaan kritis sering diterapkan. Pertanyaan tidak harus pertanyaan yang sulit ditemukan jawabannya tapi model pertanyaan tersebut dapat merangsang penalaran peserta didik. Kata tanya what, when, where, who hanya mengaktifkan hafalan dan pemahaman peserta didik, kurang menantang penalaran. Pertanyaan kritis yang menantang penalaran antara lain why, what are your reasons, which one is higher and why do you think so, etc. Pertanyaan kritis yang sering diterapkan guru dalam pembelajaran lebih menantang peserta didik untuk melakukan penalaran.

Kedua, strategi pembelajaran ini membuka sebuah alternatif baru untuk menjadikan pertanyaan kritis sebagai stimulus untuk berpikir kritis. Dalam penelitian terdahulu yang dilakukan oleh Sholihah dan Widyantoro (2014) yang berjudul the influence of higher order thinking skills (HOTS), vocabulary mastery and reading motivation on reading comprehension achievement, bermakna pengaruh HOTS, kemampuan kosa kata dan motivasi pada prestasi membaca pemahaman.

Hasil penelitian mereka membuktikan tiga kondisi positif yaitu guru dapat meningkatkan kemampuan berpikir kritis peserta didik karena dapat menunjang peningkatan prestasi membaca pemahaman Kedua, guru dan peserta didik dapat berkolaborasi untuk meningkatkan kemampuan berpikir kritis dan akhirnya dapat meningkatkan prestasi membaca pemahaman. Ketiga, kemampuan berpikir kritis peserta didik dapat meningkatkan motivasi membaca dan karena itu kemampuan membaca pemahaman menjadi meningkat.

Walaupun demikian penelitian ini berbeda dengan penelitian tersebut karena fokus dari penelitian ini adalah menerapkan strategi reciprocal teaching dan pertanyaan kritis untuk meningkatkan prestasi membaca pemahaman pada teks discussion, sehingga penelitian ini bisa dikatakan sebagai respon tindak lanjut dari hasil penelitian terdahulu.

Strategi ini juga mendukung sebuah pemahaman yang mendalam dari teks bacaan dengan kata lain pertanyaan kritis membuat peserta didik benar-benar belajar tentang isi bacaan, karena mereka di dorong untuk menggali lebih dalam makna pendapat yang disajikan dalam teks diskusi, apalagi tahapan berikutnya mereka harus menjelaskan isi bacaan ke kelompok lain. Hal ini selaras dengan apa yang dinyatakan oleh Brookhart (2010) bahwa the teaching goal behind any of the cognitive taxonomies was equipping students to be able to do transfer. "Being able to think" meant students could apply the knowledge and skills they developed during their learning to new context, yang maknanya adalah bahwa tujuan pembelajaran yang sesungguhnya adalah menyiapkan peserta didik untuk mampu mentransfer informasi yang dia peroleh ke konteks yang baru.

Peneliti melakukan perbaikan pada strategi pembelajaran yang sudah diterapkan pada siklus pertama. Kekurangan yang terjadi pada siklus pertama adalah komposisi anggota kelompok yang kurang bagus, dimana peserta didik yang memiliki kemampuan sedang dan tinggi kurang menyebar secara merata. Kondisi ini yang menyebabkan strategi pembelajaran tidak bisa berlangsung secara optimal. Kualitas kelompok menentukan keberhasilan belajar, hal ini didukung oleh pendapat Shirley (2014) yang menyatakan bahwa belajar dengan teman-teman itu lebih menyenangkan daripada belajar sendirian. Dengan saling menolong baik di dalam kelas maupun di luar kelas, membuat materi pelajaran mudah dipahami dan diingat.

Pertimbangan mengapa revisi dilakukan pada komposisi anggota kelompok adalah karena pada siklus pertama peneliti menentukan anggota kelompok berdasarkan nilai pra-siklus sehingga hasil perolehan nilai pada siklus pertama kurang maksimal, maka peneliti menganggap penting untuk menata ulang komposisi kelompok pada pelaksanaan siklus kedua, karena keberhasilan strategi pembelajaran reciprocal teaching dan pertanyaan kritis dalam memahami teks diskusi 
terletak pada keaktifan kerja kelompok dalam memecahkan masalah yang disajikan.

Sementara itu, dalam hal instrumen penelitian, peneliti menggunakan soal pilihan ganda dan uraian. Soal uraian untuk menyatakan pendapat, dimana penilaiannya dijumlahkan dengan yang pilihan ganda, bila benar semua skor 50 untuk pilihan ganda dan skor 50 untuk uraian. Peneliti menggabungkan dua model tes ini karena masing-masing model bisa saling melengkapi kelebihan dan kekurangan yang dimiliki, hal ini dikuatkan oleh pendapat Reiner (2002) bahwa soal uraian menantang peserta didik untuk menciptakan sebuah pendapat. Beberapa pendidik menggunakan soal uraian yang memiliki potensi untuk menggali kemampuan peserta didik dalam memberi alasan, menciptakan ide, menganalisis, mensintesa dan mengevaluasi.

\section{KESIMPULAN DAN SARAN}

Berdasarkan hasil analisis data dari penelitian yang telah dilakukan, maka dapat disimpulkan bahwa penerapan model pembelajaran reciprocal teaching dan pertanyaan HOT pada mata pelajaran bahasa Inggris di keterampilan membaca teks diskusi yang dilaksanakan dengan dua siklus, baik dari aspek pengetahuan, aspek sikap selama proses pembelajaran berlangsung, dimana kegiatan guru dan peserta didik diamati oleh observer, memperoleh hasil yang menunjukkan hasil yang mampu meningkatkan prestasi belajar membaca jenis teks diskusi pada peserta didik di kelas XII Lintas Minat.Dengan mempertimbangkan keuntungan dari penerapan reciprocal teaching dan pertanyaan HOT, maka diharapkan guru mata pelajaran bahasa Inggris dapat memanfaatkan strategi ini dalam pembelajaran di kelas sebagai salah satu alternatif model pembelajaran, khususnya dalam pembelajaran membaca teks bahasa Inggris.

\section{DAFTAR RUJUKAN}

Anderson, L., Krathwohl, D., Airasian, P. et al. (2001). A Taxonomy for Learning, Teaching, and Assessing: A revision of Bloom's Taxonomy of Educational Objectives, New York: Pearson, Allyn \& Bacon.

Bloom, B. S. (1956). Taxonomy of Educational Objectives, Handbook I: The Cognitive Domain, New York: David McKay Co Inc.

Kemmis, S. \& Taggart, R. (1992). The Action Research Planner. Geelong: Deakin University Press.

Kementerian Pendidikan dan Kebudayaan. (2012). Dokumen Kurikulum (2013) Bagian Pendahuluan Dokumen Kurikulum 2013: Latar Belakang dan Landasan Penyempurnaan Kurikulum.

Latief, M. (2009). Classroom Action Research in Language Learning. Malang: Universitas Negeri Malang

Reiner, C.M., Bothell, T.W., Sudweeks, R.R., \& Wood, B. (2002). Preparing Effective Essay Questions: A Self-directed Workbook for Educators. (Online) (https://testing.byu.edu/

handbooks/WritingEffectiveEssayQuestions.pdf, Diakses tanggal 23 Maret 2015).

Trianto. (2009). Mendesain Model Pembelajaran Inovatif-Progresif . Jakarta : Kencana Prenada dan Media Group 